\title{
Decreased nitrogen loading controls summer cyanobacterial blooms without promoting nitrogen-fixing taxa: Long-term response of a shallow lake
}

Tom Shatwell (1) https://orcid.org/0000-0002-4520-7916, Jan Köhler (으 https://orcid.org/0000-0003-1894-2912

DOI

10.1002/Ino.11002

Original publication date

03 September 2018

Document version

Accepted version

Published in

Limnology and Oceanography

\section{Citation (Vancouver)}

Shatwell T, Köhler J. Decreased nitrogen loading controls summer cyanobacterial blooms without promoting nitrogen-fixing taxa: Long-term response of a shallow lake. Limnology and Oceanography. 2019;64(S1):S166-S78. 
Decreased nitrogen loading controls summer cyanobacterial blooms without promoting nitrogen-fixing taxa: long-term response of a shallow lake

Tom Shatwell*, Jan Köhler

Leibniz-Institute of Freshwater Ecology and Inland Fisheries, Berlin, Germany

Author email addresses: tom.shatwell@ufz.de, koehler@igb-berlin.de

* Corresponding author details: Leibniz-Institute of Freshwater Ecology and Inland Fisheries, Müggelseedamm 310, 12587 Berlin, Germany.

Current address: Helmholtz Centre for Environmental Research, Brückstr. 3a, 39114, Magdeburg, Germany.

This is the peer reviewed version of the following article: Shatwell, T., Köhler, J., 2019. Decreased nitrogen loading controls summer cyanobacterial blooms without promoting nitrogen-fixing taxa: long-term response of a shallow lake. Limnol. Oceanogr. 64: S166S178, doi: 10.1002/lno.11002, which has been published in final form at https://doi.org/10.1002/lno.11002. This article may be used for non-commercial purposes in accordance with Wiley Terms and Conditions for Use of Self-Archived Versions.

\begin{abstract}
The effectiveness of controlling nitrogen $(\mathrm{N})$ to manage lake eutrophication is debated. Longterm, whole-lake case studies are required to determine whether diazotrophic cyanobacteria can fix sufficient $\mathrm{N}$ to offset a reduction of $\mathrm{N}$ inputs. We document the recovery of shallow, productive Lake Müggelsee (Germany) over 37 years (sampling interval 1 - 2 weeks) during a decrease of $\mathrm{N}$ and phosphorus (P) loading of $79 \%$ and $69 \%$ respectively. Nitrogen concentrations in the lake responded immediately to loading reduction whereas $\mathrm{P}$ concentrations remained elevated for about 20 years. Total nitrogen (TN) in the lake was always lower than TN in the inflow. Accordingly, estimated denitrification and N-burial rates substantially exceeded $\mathrm{N}_{2}$ fixation rates in the long term. Phosphorus was growth limiting in spring whereas $\mathrm{N}$ was clearly limiting in summer due to high sediment $P$ release. TN:TP ratios, normalized to phytoplankton biovolume by regression, were 25.5 (weight) in spring and 3.3 in summer. During the study period, dissolved inorganic N (DIN) concentrations in summer decreased and the duration of low DIN concentrations increased by ca. 100 days. The biovolume of cyanobacteria and total phytoplankton decreased by $89 \%$ and $76 \%$ respectively. The proportion of $\mathrm{N}_{2}$-fixing cyanobacteria during summer decreased from $36 \%$ to $14 \%$ of the total phytoplankton biovolume. The total concentration of heterocysts and estimated total $\mathrm{N}_{2}$-fixation did not change over time. In the long term, decreasing $\mathrm{N}$-inputs effectively controlled summer cyanobacteria including $\mathrm{N}_{2}$ -
\end{abstract}


fixing taxa, which did not compensate for the N-deficit. A P-only control strategy would not have been as successful. 


\section{Introduction}

The role of nitrogen $(\mathrm{N})$ limitation of autotrophs in lakes has been debated for decades. Eutrophication management has focused on controlling phosphorus (P) inputs since the 1970s when its importance was indisputably demonstrated (Schindler 1977). Currently there is a lack of scientific consensus about whether eutrophication is best managed by controlling $\mathrm{P}$ alone, or by controlling both N and P (Lewis and Wurtsbaugh 2008; Schindler et al. 2008; Conley et al. 2009; Schindler et al. 2016; Cotner 2017).

Arguments in favor of controlling only $\mathrm{P}$-inputs are based on the premise that $\mathrm{P}$ is the ultimate (long-term) limiting nutrient, whereas $\mathrm{N}$ limitation is only temporary and a symptom of Poverfertilization (Wang and Wang 2009; Schindler 2012). N-limitation may favor diazotrophic cyanobacteria, which can satisfy their N-requirements by fixing atmospheric N. This input of atmospheric $\mathrm{N}$ is proposed to accumulate in the ecosystem over time and eventually replace any decrease in external $\mathrm{N}$-inputs until $\mathrm{P}$ again becomes the primary limiting nutrient (Schindler et al. 2008). According to this perspective, not only is controlling $\mathrm{N}$ inputs expensive, but also futile with the additional side effect of shifting the summer phytoplankton community towards toxic $\mathrm{N}_{2}$-fixing cyanobacteria (Welch 2009).

On the other hand, dual $\mathrm{N}$ and $\mathrm{P}$ control strategies are based on the argument that $\mathrm{N}$ and $\mathrm{P}$ colimit growth (Harpole et al. 2011; Bracken et al. 2015) and $\mathrm{N}$ and $\mathrm{P}$ enrichment produces strong synergistic effects on eutrophication (Elser et al. 2007; Paerl et al. 2016). Anthropogenic activities have increased N-loading to freshwaters relative to P (Peñuelas et al. 2013). Excess $\mathrm{N}$ promotes summer blooms of cyanobacteria (Glibert et al. 2014) and can increase the toxicity of non-diazotrophic forms (Gobler et al. 2016). Accordingly, focusing only on P may not only be less effective at mitigating eutrophication and reducing harmful cyanobacterial blooms than dual $\mathrm{N}$ and $\mathrm{P}$ control, but also cause excess $\mathrm{N}$ to be exported to downstream $\mathrm{N}$-sensitive ecosystems, like estuaries and coastal areas (Howarth and Marino 2006; Paerl 2009).

Therefore, the effectiveness of managing $\mathrm{N}$-inputs to mitigate eutrophication in lakes hinges on whether diazotrophic cyanobacteria can replace the resulting N-deficit in the long term through $\mathrm{N}_{2}$ fixation. Some long-term studies demonstrate that $\mathrm{N}_{2}$ fixation can compensate loading reduction in the long term (Schindler et al. 2008). However, somewhat counter-intuitively, strong N-limitation often does not promote - and may even decrease - diazotrophic cyanobacteria relative to other taxa (Dolman et al. 2012; Gobler et al. 2016). Moreover, evidence suggests that $\mathrm{N}_{2}$ fixation in lakes only satisfies a small proportion of the annual $\mathrm{N}$ requirements (Ferber et al. 2004; Dolman et al. 2012; Gobler et al. 2016), predominantly due to physical control by temperature, irradiance and hydrology (Paerl and Otten 2016). Retention time also determines whether fixed $\mathrm{N}$ can accumulate in the long term (Schindler 1981; Howarth and Marino 2006; Scott and McCarthy 2010; Scott and Grantz 2013; Grantz et al. 2014). 
Although there is much evidence in support of controlling $\mathrm{N}$ in freshwater, the rationale behind this has been criticized as being "based solely on short-term, small scale studies, none of them at long-term ecosystem scales" (Schindler et al. 2017). Accordingly, D. W. Schindler (2012) stated that "long-term, whole-ecosystem experiments and case histories of lake recovery provide the only reliable evidence for policies to reduce eutrophication." Here we present a 37 year ecosystem-scale case history of the recovery of Lake Müggelsee (Germany) after a decrease of $\mathrm{N}$ and P inputs by $79 \%$ and 69\%, respectively. Lake Müggelsee is one of Germany's best studied lakes, offering a rare opportunity to observe in detail the long-term effects of nutrient reduction on the phytoplankton community structure and whole ecosystem response. The aim of our study was to investigate 1) how in-lake $\mathrm{N}$ and $\mathrm{P}$ concentrations responded to load reduction, 2) which nutrients are growth limiting for phytoplankton, 3) if $\mathrm{N}$ loading reduction favored diazotrophic cyanobacteria, 4) whether $\mathrm{N}_{2}$ fixation compensated the decrease in external $\mathrm{N}$ load reduction in the long term, and 5) whether dual $\mathrm{N}$ and $\mathrm{P}$ control can effectively mitigate eutrophication and summer cyanobacterial blooms. Our hypothesis was that decreased $\mathrm{N}$ loading would immediately reduce in-lake $\mathrm{N}: \mathrm{P}$ ratios and eventually increase $\mathrm{N}$ limitation due to ongoing $\mathrm{P}$ release from sediments of shallow lakes during summer. Moreover, we hypothesized that $\mathrm{N}_{2}-$ fixing cyanobacteria would respond to lower dissolved inorganic $\mathrm{N}$ (DIN) concentrations by increasing $\mathrm{N}_{2}$ fixation per biovolume, but that the absolute $\mathrm{N}_{2}$ fixation would not exceed denitrification and thus not alleviate summer $\mathrm{N}$ limitation in the long term in this shallow lake.

\section{Methods}

\section{Study site and sampling}

Lake Müggelsee $\left(52.44^{\circ} \mathrm{N}, 13.65^{\circ} \mathrm{E}\right.$ ) is a shallow (mean depth $4.9 \mathrm{~m}$, maximum depth $8 \mathrm{~m}$ ), polymictic lake in Berlin, Germany with a surface area of $7.3 \mathrm{~km}^{2}$. The lake is fed by the River Spree from a $7,000 \mathrm{~km}^{2}$ catchment, which is $36 \%$ forest and $42 \%$ agricultural land and has a population of 720,000 . The theoretical retention time of the lake is 6 to 12 weeks. From 1979 to 1986, water samples were taken from the deepest point of the lake at weekly intervals from spring to autumn and every two weeks in winter. Water was sampled with a 5 L Friedinger sampler at $0.5 \mathrm{~m}, 4 \mathrm{~m}$, and $7 \mathrm{~m}$ depth and volumetrically integrated. From 1987 to 2016, volumetrically weighted integrated samples were taken from 21 subsamples from five different points on the lake. The change in sampling routines had little influence on the concentrations of phytoplankton or nutrients (Driescher et al. 1993). On the same days as the lake sampling, inflow samples were taken in the River Spree just upstream of its mouth into the lake.

\section{Phytoplankton}

Phytoplankton samples were fixed with Lugol's solution and abundances of individual species or algal groups were counted with an inverted microscope. The relevant dimensions of at least 50 
cells per taxon were measured, and the biovolumes were calculated assuming simple geometrical bodies. The length and number of heterocysts of each filament and the area of each cyanobacterial colony were determined.

\section{Nutrient concentrations, loads and balance}

Dissolved and particulate nutrients were separated by filtration $(0.45 \mu \mathrm{m})$. Soluble reactive $\mathrm{P}$ (SRP) was measured photometrically according to (Murphy and Riley 1962). Total P (TP) and dissolved P (DP) were determined as SRP after acid digestion at $160{ }^{\circ} \mathrm{C}$ for six hours. Standard methods were used to measure the concentrations of ammonium (DEV 1983, E5) and nitrate + nitrite by photometry (DEV 2012, D9) or ion chromatography (DEV 2009, D20). Total N (TN) and dissolved $\mathrm{N}(\mathrm{DN})$ were measured after catalytic oxidation as chemoluminescence in $\mathrm{N}$ analyzers. Dissolved inorganic $\mathrm{N}$ was calculated as the sum of nitrate $\left(\mathrm{NO}_{3}-\mathrm{N}\right)$ and ammonium $\left(\mathrm{NH}_{4}-\mathrm{N}\right)$. Particulate $\mathrm{N}$ and $\mathrm{P}$ ( $\mathrm{PN}$ and $\mathrm{PP}$ ) were calculated as the difference between the total and dissolved concentrations of the respective nutrient. All nutrient ratios given in the text refer to ratios by weight.

Daily discharge data for the inflows (Q) were calculated by the local authorities using permanent records of a gauge $1.2 \mathrm{~km}$ upstream of the lake and hydraulic models. The nutrient load was calculated as the product of the daily discharge rates and the inflow concentration (measured weekly, interpolated to daily intervals), aggregated into monthly means. The withdrawal of lake water by direct abstraction (until 1991) and by bank filtration was measured as pumping rates by the Berlin Water Works supplied as monthly totals. The bank filtration rates were corrected for the mean share of real groundwater based on tracer measurements and models using the monitored groundwater table height. To estimate the nutrient balance, water withdrawal via bank filtration $\left(\mathrm{Q}_{\text {filtr }}\right)$ was assumed to remove only particulate nutrients $\left(\mathrm{c}_{\text {part }}\right)$. Nutrient retention was then calculated as the difference between the nutrient load and nutrient export, which comprises of fluxes via the outflowing river $\left(\left(\mathrm{Q}-\mathrm{Q}_{\text {filtr }}-\mathrm{Q}_{\text {pipe }}\right) \times \mathrm{c}_{\text {total }}\right)$, bank filtration $\left(\mathrm{Q}_{\text {filtr }} \times \mathrm{c}_{\text {part }}\right)$, and direct water withdrawal $\left(Q_{\text {pipe }} \times c_{\text {total }}\right)$, where $Q_{\text {pipe }}$ indicates the volume of surface water taken by the water works (only until 1991) and $c_{\text {total }}$ the concentration of total nutrients. We estimated $\mathrm{N}_{2}$ fixation using published data on fixation rates (either the median of the published rates or calculated by models using median parameter values) per heterocyst (Hadas et al. 2012; Kolzau et al. 2018), or per heterocyst and mean underwater light (Ferber et al. 2004). We then used the median of these three different estimates of fixation rates for the $\mathrm{N}$ balance. Denitrification plus $\mathrm{N}$ sedimentation was calculated as $\mathrm{N}$ retention plus estimated $\mathrm{N}_{2}$ fixation.

\section{Physical characteristics}

During sampling, vertical profiles of temperature and oxygen were measured every $0.5-1.0 \mathrm{~m}$ at the deepest point of the lake. Surface temperature was estimated as the mean temperature in the upper $1 \mathrm{~m}$ layer, and bottom temperature as the mean temperature in the $1 \mathrm{~m}$ layer centered at 
the mean lake depth. The mean daily underwater light intensity $I_{m}$ (photosynthetically available radiation, PAR) in the mixed layer of depth $h$ was calculated according to the Lambert-Beer law as $I_{m}=I 0(\varepsilon h)^{-1}\left(1-e^{-\varepsilon h}\right)$, where $\varepsilon$ is the light attenuation coefficient and $I_{0}$ is the PAR just below the water surface. Io was estimated using global radiation from ERA-Interim climate reanalysis (Dee et al. 2011) and converted to PAR assuming $4.56 \mu$ mol photons $\mathrm{J}^{-1}$, a PAR proportion of $50 \%$, and $10 \%$ reflection and backscattering at the water surface. The mixed layer depth $h$ was assumed to be $4.9 \mathrm{~m}$, the mean lake depth, when the lake was isothermal. The lake was considered stratified when the difference between surface and bottom temperature exceeded $1^{\circ} \mathrm{C}$, in which case $h$ was estimated as the depth of maximum temperature gradient. The attenuation coefficient was measured using two spherical PAR sensors (LI-193SA, LICOR, Nebraska) at $0.75 \mathrm{~m}$ and $1.25 \mathrm{~m}$ depth at the end of a jetty located on the northern lake shore from 1993 to 2003, and from 2004 on, from a monitoring platform located $300 \mathrm{~m}$ from the northern shore. Prior to that and at times when the PAR sensors were unavailable, $\varepsilon$ was estimated from the Secchi depth using a relationship based on parallel measurements according to Shatwell et al. (2016) and Nicklisch et al. (2008). Oxygen was measured prior to April 1992 by Winkler titration. From May 1992 to May 2011 vertical oxygen profiles were recorded with H2O multiprobes (Hydrolab Corporation, USA) and afterwards with optical sensors in multiparameter sondes (Yellow Springs Instruments, USA).

\section{Statistics}

Temporal means were calculated by first linearly interpolating the data over time at a daily interval and then averaging the data over the days in the period of interest. For seasonal means, winter was defined as January to March, spring as April to June, summer as July to September, and autumn as October to December. Beta regressions with a logit link function were used to analyze relationships where the dependent variables were proportions, including the biovolume of $\mathrm{N}_{2}$-fixing phytoplankton relative to total cyanobacteria biovolume and relative to total phytoplankton biovolume. Beta regressions are useful when the dependent variable is bounded between 0 and 1 and the error distribution cannot be assumed to be binomial, as is the case with relative biovolume. The relationships between phytoplankton biovolume and nutrient concentrations were analyzed using generalized linear models. We used a gamma error distribution and the identity link function because biovolume variance increased roughly proportionally to the mean. Standard linear regressions were used in other cases. Nutrient ratios were log-transformed. Analyses were performed with R version 3.4.0 (R Core Team 2017) using the betareg package (Cribari-Neto and Zeileis 2010). Unless otherwise stated, means \pm standard deviation are given in the text. 


\section{Results}

\section{External loading}

The external loading of $\mathrm{N}$ and $\mathrm{P}$ to lake Müggelsee decreased significantly between the late 1970s and 2016 (p < 0.001, Fig. 1a). Total $\mathrm{N}$ (TN) loads decreased from $140 \pm 38 \mathrm{~g} \mathrm{TN} \mathrm{m}^{-2} \mathrm{a}^{-1}$ in the 1980 s to $30 \pm 11 \mathrm{~g} \mathrm{TN} \mathrm{m}^{-2} \mathrm{a}^{-1}$ in the decade 2007-2016. Total P (TP) loads decreased from 6 \pm 1 to $2 \pm 0.4 \mathrm{~g} \mathrm{TP} \mathrm{m}^{-2} \mathrm{a}^{-1}$ in the same period. The reasons for the decrease in nutrient loading were a $47 \%$ decrease in annual mean discharge from the inflowing River Spree from $9.9 \pm 1.6$ in the $1980 \mathrm{~s}$ to $5.2 \pm 0.9 \mathrm{~m}^{3} \mathrm{~s}^{-1}$ (2007-2016), combined with a decrease in nutrient concentrations in the inflows from $3016 \pm 301$ to $1224 \pm 231 \mu \mathrm{g} \mathrm{TN} \mathrm{L}{ }^{-1}$ and $138 \pm 9$ to $87 \pm 12 \mu \mathrm{g} \mathrm{TP} \mathrm{L}{ }^{-1}$. Since TN concentrations decreased more rapidly than TP concentrations, TN : TP in the lake inflow decreased accordingly from about 21.9 in the 1980s to 14.1 (by weight) in the decade 2007 2016 but the annual mean ratios did not fall below the Redfield ratio and remained within the range of $\mathrm{N}+\mathrm{P}$ co-limitation suggested by Guildford and Hecky (2000) (Fig. 1b). There were large seasonal variations in the inflow nutrient ratios. In the 1980s, mean inflow TN : TP was 33 in winter compared to 14 in summer. In the decade $2007-2016$, TN : TP was 24 in winter compared to 8.3 in summer.

\section{Lake nutrient concentrations and ratios}

The TN concentrations in the lake declined immediately and in parallel with the decline in concentrations in the inflow (Fig. 2a). Over the study period, the average TN concentrations in the lake were $15 \%$ lower than concentrations in the inflow, with this margin narrowing by about $3 \%$ per decade $(\mathrm{p}<0.001)$. Thus, lake TN concentrations seemed to approach equilibrium with the inflow concentrations, as particularly evident in recent years. This was reflected in the $\mathrm{N}$ balance of the lake, which always showed net retention of $\mathrm{N}$, but a decreasing amount of retained $\mathrm{N}$ over time ( $\mathrm{p}<0.001$ ), which seems to be approaching zero (Fig. 2c). Accordingly, the estimated retained $\mathrm{N}$ was $25.6 \pm 7.5 \mathrm{~g} \mathrm{~N} \mathrm{~m}^{-2} \mathrm{a}^{-1}$ in the $1980 \mathrm{~s}$, and only $5.6 \pm 2.9 \mathrm{~g} \mathrm{~N} \mathrm{~m}^{-2} \mathrm{a}^{-1}$ in the decade 2007 - 2016. Estimated $\mathrm{N}_{2}$ fixation was on average $0.79 \pm 0.52 \mathrm{~g} \mathrm{~N} \mathrm{~m}^{-2} \mathrm{a}^{-1}$ and did not change significantly over time (Fig. 2d). Estimated denitrification plus sedimentation rates were substantially higher than $\mathrm{N}_{2}$ fixation rates and decreased with decreasing $\mathrm{N}$ loading in parallel with $\mathrm{N}$ retention (Fig. $2 \mathrm{~d}$ ).

In contrast, following the decrease in external P-loading, in-lake $\mathrm{P}$ concentrations declined with a substantial delay (Fig. 2b). In-lake TP concentrations were higher than inflow concentrations in most years, particularly between 1988 and 1992, and only fell steadily below inflow concentrations from 2011 on. The P-balance indicated that the lake released P (i.e. negative retention) on average at annual scales from the mid-1980s until 2010, with variation between years (Fig. 2e). In the 1980s, the P-balance showed strong P retention in spring and very strong $\mathrm{P}$ release during summer. Spring $\mathrm{P}$ retention then decreased to approximately stable levels by 
around 1990 and summer P release roughly stabilized about 5 years later. During the period 1996 to 2010 , spring $\mathrm{P}$ retention was $2.23 \mathrm{mg} \mathrm{P} \mathrm{m}^{-2} \mathrm{~d}^{-1}$ whereas summer $\mathrm{P}$ release was $3.65 \mathrm{mg} \mathrm{P} \mathrm{m}^{-2}$ $\mathrm{d}^{-1}$ with an annual average release of $0.36 \mathrm{~g} \mathrm{P} \mathrm{m}^{-2} \mathrm{a}^{-1}$. It appears that the lake required two decades to fully recover from $\mathrm{P}$ loading and only became a net P sink again around 2011.

The lake-internal processes caused a distinct seasonal pattern in the nutrient concentrations (Fig. 3). Soluble reactive $\mathrm{P}$ (SRP) concentrations were lowest in winter and spring and highest in summer reflecting internal loading from the sediment (Fig. 3a, see also Supplementary Fig. S1). Dissolved inorganic N (DIN) concentrations were highest in winter and lowest in summer (Fig. 3b). There was a decreasing trend in TP and SRP during winter and in TP also during spring and summer, but there was no significant change in the autumn concentrations (Table 1, Fig. 3a). Nitrogen (TN and DIN) concentrations decreased significantly in all seasons (Table 1, Fig. 3b).

Mean seasonal N:P ratios (total and dissolved nutrients) were highest in winter and lowest in summer when they fell below the Redfield ratio (Table 1, Fig. 4). Both TN:TP and DIN:SRP ratios decreased significantly over time. The particulate ratio PN:PP was much less variable than the dissolved nutrient ratio and there was a decreasing trend in spring and summer. Until the early 1990s, PN:PP was generally above Redfield, but afterwards was generally below this value (Fig. 4c). In 2015 and 2016, PN:PP rose above Redfield in winter and spring. Mean seasonal carbon to $\mathrm{N}$ ratios $(\mathrm{C}: \mathrm{N})$ were between 5.6 and 6.2 by weight and increased over time by about $2.5 \%$ per year in spring and summer and by about $3.5 \%$ per year in autumn and winter. During the mid-2000s, the $\mathrm{C}: \mathrm{N}$ ratio switched from predominantly below to predominantly above the Redfield ratio (Fig. 4d), noting that there were no data before 1999.

The total duration of seasonal low DIN $(<0.2 \mathrm{mg} / \mathrm{L})$ periods increased significantly $(\mathrm{p}<0.0001)$ by around 100 days over the course of the study period (Fig. 5). In the 1980s, DIN was continuously below $0.2 \mathrm{mg} \mathrm{L}^{-1}$ on average from mid-July until mid-August each year, whereas in the decade from 2007 to 2016, these periods extended from the end of May until late September. The total duration of low SRP periods $\left(<20 \mu \mathrm{g} \mathrm{L}^{-1}\right)$ did not change significantly over time $(\mathrm{p}=$ 0.23, Fig. 5). However, there was a trend for continuous periods of low SRP to begin earlier (March 8 on average in the 1980s compared to February 21 in 2007-2016, p = 0.005).

\section{Phytoplankton}

Phytoplankton in Müggelsee generally showed a bimodal seasonal pattern with a spring peak of diatoms around April and a summer peak around late July (Fig. 6). Nitrogen-fixing cyanobacteria (mostly Aphanizomenon sp. and Anabaena sp. (alias Dolichospermum sp.)) showed a small but regular peak in late spring around May, sometimes before or after the clear water phase, and a much stronger development in July and August. This pattern was also reflected in the $\mathrm{N}_{2}$-fixing proportion of the total phytoplankton biovolume (Fig. 6). 
The annual mean phytoplankton biovolume decreased significantly by $0.26 \pm 0.04 \mathrm{~mm}^{3} \mathrm{~L}^{-1} \mathrm{a}^{-1}$ (p $<<0.001$ ) from $11.7 \pm 3.1 \mathrm{~mm}^{3} \mathrm{~L}^{-1}$ in the 1980 s to $2.8 \pm 1.2 \mathrm{~mm}^{3} \mathrm{~L}^{-1}$ in the decade $2007-2016$ (Fig. 7a), and the mean summer cyanobacteria biovolume decreased from $10.3 \pm 4.8 \mathrm{~mm}^{3} \mathrm{~L}^{-1}$ to $1.2 \pm 0.6 \mathrm{~mm}^{3} \mathrm{~L}^{-1}$ in the same period. The mean summer biovolume of $\mathrm{N}_{2}$-fixing taxa also decreased significantly by $0.18 \pm 0.04 \mathrm{~mm}^{3} \mathrm{~L}^{-1} \mathrm{a}^{-1}(\mathrm{p}=0.0002)$ from $6.7 \pm 4.2 \mathrm{~mm}^{3} \mathrm{~L}^{-1}$ in the 1980 s to $0.7 \pm 0.3 \mathrm{~mm}^{3} \mathrm{~L}^{-1}$ in the decade $2007-2016$. Not only did the biovolume of $\mathrm{N}_{2}$-fixing taxa decrease, but also their proportion of the total biovolume $(p=0.002)$ as well as their proportion of the cyanobacteria ( $\mathrm{p}=0.03$, Fig. $7 \mathrm{~b}$ ). Whereas in the $1980 \mathrm{~s}, \mathrm{~N}_{2}$-fixing taxa constituted on average $62 \%$ of the cyanobacteria and $36 \%$ of the total biovolume in summer, by the last decade of the time series they constituted $48 \%$ of the cyanobacteria and only $14 \%$ of the total summer phytoplankton.

The mean phytoplankton biovolume was significantly related to TP and TN in both spring and summer (Fig. 8, Table 2). There were however considerable differences in these relationships between the seasons. The relationship between biovolume and TP was stronger in spring than in summer, whereas the relationship between biovolume and TN was stronger in summer than in spring (see pseudo $\mathrm{R}^{2}$ values in Table 2). Accordingly, spring phytoplankton biovolume decreased proportionally to $\mathrm{P}$, whereas summer biovolume decreased proportionally to $\mathrm{N}$. Moreover, the phytoplankton biovolume yield per unit $\mathrm{P}$ (slope of the biovolume vs TP regression line in Table 2) was 4 times higher in spring $\left(0.150 \mathrm{~mm}^{3} \mu \mathrm{g}^{-1} \mathrm{TP}\right)$ than it was in summer $\left(0.037 \mathrm{~mm}^{3} \mu \mathrm{g}^{-1} \mathrm{TP}\right)$. On the other hand, the biovolume yield per unit TN was about twice as high in summer $\left(11.23 \mathrm{~mm}^{3} \mathrm{mg}^{-1} \mathrm{TN}\right)$ as it was in spring $\left(5.89 \mathrm{~mm}^{3} \mathrm{mg}^{-1} \mathrm{TN}\right)$. The ratio of the reciprocals of these slopes gives the nutrient ratio normalized to phytoplankton biovolume. Accordingly, the biovolume-normalized ratio of $\mathrm{N}$ to $\mathrm{P}$ in spring was 25.5 by weight and thus much higher than the Redfield ratio of 7.2, whereas in summer the normalized ratio was 3.3. At an annual scale, the biovolume-normalized N:P ratio was 14.6.

The mean proportion of $\mathrm{N}_{2}$-fixing cyanobacteria within the total biomass during summer was significantly positively related to the PN:PP ratio $(\mathrm{p}=0.01)$, the DIN:SRP ratio $(\mathrm{p}=0.001)$, and the DIN concentration $(\mathrm{p}=0.01)$. It was negatively related to the $\mathrm{C}: \mathrm{N}$ ratio $(\mathrm{p}=0.04$, excluding 2009 , which deviated from the mean by more than 3 SDs, or $p=0.08$ otherwise), and the mean light in the mixed layer $\left(\mathrm{p}=0.02\right.$ ). Net specific growth rates of $\mathrm{N}_{2}$-fixing taxa, calculated from the change in biovolume over time as a measure of relative growth performance, were on average highest in April $\left(0.08 \mathrm{~d}^{-1}\right)$ and June $\left(0.09 \mathrm{~d}^{-1}\right)$ preceding the regular May and July maxima. In June, the specific growth rates of $\mathrm{N}_{2}$-fixing taxa were positively related to mean underwater PAR $(\mathrm{p}=0.009)$. In April, the difference in specific growth rates of $\mathrm{N}_{2}$-fixing and non- $\mathrm{N}_{2}$-fixing taxa (as a measure of relative advantage of $\mathrm{N}_{2}$-fixers) was positively related to $\operatorname{PAR}(\mathrm{p}=0.03)$. Otherwise the net specific growth rates in April and June were unrelated with nutrients or water temperature. 
The mean summer concentration of heterocysts in lake water did not change significantly over time $(\mathrm{p}=0.33)$. Moreover, the concentration of heterocysts in lake water was not related to the DIN concentration ( $p=0.10$, Fig. 9a). However, the number of heterocysts per unit biovolume of $\mathrm{N}_{2}$-fixing species increased sharply at low DIN concentrations (Fig. 9b). The frequency of heterocysts was given in terms of DIN concentration $\left(\mathrm{mg} \mathrm{L}^{-1}\right)$ by:

Heterocyst frequency $\left(\right.$ no. $\left.\mu \mathrm{g}^{-1}\right)=48.0( \pm 1.2) \times \mathrm{DIN}^{-0.69( \pm 0.08)}\left(\mathrm{p}<<0.0001, \mathrm{t}=8.2, \mathrm{df}=33, \mathrm{R}^{2}\right.$ $=0.67)$

\section{Physical characteristics}

The annual mean light extinction decreased by $0.018 \mathrm{~m}^{-1} \mathrm{a}^{-1}(\mathrm{p}<<0.001)$ from $1.73 \pm 0.30 \mathrm{~m}^{-1}$ in the 1980 s to $1.16 \pm 0.19 \mathrm{~m}^{-1}$ in the years $2006-2014$. Accordingly, the mean PAR in the mixed layer (= mean lake depth when unstratified) during summer increased by $0.15 \pm 0.03 \mathrm{~mol} \mathrm{~m}^{-2} \mathrm{~d}^{-1}$ $\mathrm{a}^{-1}(\mathrm{p}<<0.001)$. Mean summer surface temperature increased by $0.051{ }^{\circ} \mathrm{C} \mathrm{a}^{-1}(\mathrm{p}=0.002)$, but there was no significant increase in the difference between surface and bottom temperatures $(\mathrm{p}=$ 0.11 ) suggesting no general increase in stratification. Based on the high-frequency temperature profiles available since 2004, the median and maximum duration of stratification events was 6 hours and 20 days, respectively (see Supplementary Fig. S1). We detected no significant increase in the frequency or total duration of summer stratification events longer than 1 day since 2004. Water near the sediment periodically became depleted in oxygen during extended stratification events, but otherwise remained oxic (Fig. S1).

\section{Discussion}

While there are many examples of lakes in which reduction of $\mathrm{P}$ loading successfully decreased phytoplankton biomass (Jeppesen et al. 2005), there are very few long-term, whole ecosystem studies that document whether a combined reduction of $\mathrm{N}$ and $\mathrm{P}$ loading is useful in controlling eutrophication. Moss et al. (2005) found that phytoplankton biomass declined in a shallow lake as N inputs and concentrations decreased. Köhler et al. (2005) analyzed data in Lake Müggelsee until 2003 and found that phytoplankton biomass decreased in parallel with $\mathrm{P}$ inputs in spring and with $\mathrm{N}$ inputs in summer, but the biomass of the $\mathrm{N}_{2}$-fixing Aphanizomenon flos-aquae did not change. Since the study of Köhler et al. (2005), an additional 13 years of data have become available for the present study, which shows that $\mathrm{N}$ and P loads continued to decline after 2003, as did the phytoplankton biomass. The new analysis presented here demonstrated that not only did the biomass of summer cyanobacteria decrease in parallel to TN concentration, but the proportion of $\mathrm{N}_{2}$-fixing species within the total phytoplankton decreased as well. Our results therefore confirm that a decrease in $\mathrm{N}$ and $\mathrm{P}$ loading, and the concomitant decrease in DIN concentrations in the lake, did not favor $\mathrm{N}_{2}$-fixing cyanobacteria over other phytoplankton groups. Furthermore, $\mathrm{N}_{2}$ fixation did not exceed $\mathrm{N}$ losses through denitrification and burial and did not compensate for the decrease in $\mathrm{N}$ inputs within the 37 year study period. 
Our results highlighted the importance of seasonality of dissolved nutrient concentrations. At annual scales, total phytoplankton biovolume was significantly correlated with both TN and TP, where a greater percentage of the variance was explained by TN than by TP. Moreover, the $\mathrm{TN}$ :TP ratio in inflows was always above the Redfield ratio yet within the range of $\mathrm{N}+\mathrm{P}$ colimitation identified by Guildford and Hecky (2000). So which nutrient was responsible for controlling the biomass? We found strong evidence that $\mathrm{P}$ was biomass-limiting in spring, whereas $\mathrm{N}$ was limiting in summer, which occurs regularly in shallow polymictic lakes (Dolman et al. 2016). The lower TP concentrations in the inflow compared to the lake demonstrated the importance of $\mathrm{P}$ remobilization from the sediments, which delayed a decline in TP for about 20 years, causing stronger $\mathrm{N}$-limitation in summer.

Our finding of $\mathrm{P}$ limitation in spring and $\mathrm{N}$ limitation in summer was based on regressions of phytoplankton biovolume on total nutrient concentrations. The diagnosis of nutrient limitation on the basis of these kinds of regressions has been criticized for a number of reasons (Lewis and Wurtsbaugh 2008). Firstly, chlorophyll a vs nutrient relationships are often analyzed on log-log plots, which can obscure the enormous variability in the relationship. Secondly, chlorophyll a and $\mathrm{N}$ and $\mathrm{P}$ are essential components of biomass, so there must necessarily be a relationship between them. This co-linearity means that total N:P ratios, which generally reflect particulate ratios, are not reliable indicators of nutrient limitation (Schindler 2012). We avoided the first issue by using linear rather than log-transformed variables, and reduced the second by using phytoplankton biomass rather than chlorophyll a. Moreover, we can argue that a given quantity of nutrient must necessarily yield a higher biomass as the degree of nutrient limitation increases (internal nutrient quota decreases). Furthermore, the nutrient-biomass relationship should be less variable as the non-structural internal nutrient pools of phytoplankton are restricted to narrower ranges. Therefore, untransformed biomass-nutrient relationships are useful in diagnosing relative degrees of nutrient limitation. Accordingly our results of a higher yield (slope of the biovolume vs total $\mathrm{N}$ or $\mathrm{P}$ regression) and lower residual deviance (higher pseudo $\mathrm{R}^{2}$ ) provide strong evidence that $\mathrm{P}$ was much more strongly limiting in spring than it was in summer and $\mathrm{N}$ much more strongly limiting in summer than in spring. The ratios of the biomass yields of $\mathrm{P}$ and $\mathrm{N}$ (regression slopes) are arguably more useful than the N:P ratios themselves because the yields are normalized to phytoplankton biovolume and thus provide a better indication of the average cellular nutrient status. Based on the nutrient yields, we found that $\mathrm{N}: \mathrm{P}$ normalized to biovolume in Lake Müggelsee was well above Redfield in spring and well below Redfield in summer. Schindler (2012) stated that correlations of chlorophyll with one nutrient that are slightly better than with another nutrient are more likely to reflect relative differences in analytical errors than in nutrient limitations. However the differences we observed over the nearly 4 decades are too large and consistent to be attributed to analytical error. The trends we observed in particulate nutrients (falling PN:PP and rising particulate $\mathrm{C}: \mathrm{N}$ ratios, both crossing the Redfield ratio) also reflected an increasing $\mathrm{N}$-deficit. Combined with the very low observed dissolved $\mathrm{N}$ 
concentrations, we conclude that $\mathrm{N}$ was the predominant limiting nutrient in summer, and that the decrease in $\mathrm{N}$ inputs increased $\mathrm{N}$-limitation in the long term without favoring $\mathrm{N}_{2}$-fixing cyanobacteria.

Internal $\mathrm{P}$ loading can remain high for decades after nutrient input reduction due to legacy loads of P (McCrackin et al. 2017) so that $\mathrm{N}$ limitation during the non-equilibrium phase may only be temporary. In Lake Müggelsee, the absence of decreasing trends in summer SRP concentrations and the fact that the lake was on average a net P-source until around 2010 suggests that the lake may have only very recently reached final equilibrium with P-inputs. This recovery time of about 20 years seems reasonable compared to other lakes (Jeppesen et al. 2005). The bulk of internal P loading in summer likely originated from mineralization of freshly sedimented $\mathrm{P}$ from the previous winter and spring. Mineralization of fresh organic material under predominantly aerobic conditions can be a substantial internal source of P (Hupfer and Lewandowski 2005; Song and Burgin 2017) or even the driving force of internal P loading (Sinke et al. 1990). Moreover, undisturbed sediment cores from Müggelsee incubated under aerobic conditions retained $\mathrm{P}$ at spring temperatures $\left(15^{\circ} \mathrm{C}\right)$ but released $\mathrm{P}$ at summer temperatures $\left(20^{\circ} \mathrm{C}\right)$ due to a shift in the balance between mineralization and P-iron binding (Hupfer and Lewandowski 2008). This is consistent with the results of our P-balance, showing that P-retention in spring constituted about two thirds of the P-release in summer, which was too high to induce summer P-limitation. We conclude that the reduction in $\mathrm{N}$ loading and the corresponding strong and persistent $\mathrm{N}$ limitation in summer is what ultimately kept the summer cyanobacterial blooms at bay. Moss et al. (2005) also found that high internal $\mathrm{P}$ release in summer in a shallow lake prevented seasonal Plimitation and caused phytoplankton biomass to decrease in parallel with declining $\mathrm{N}$ concentrations and loading. This highlights an important point: although TN:TP ratios in the lake inflows were always above Redfield in the annual mean, the strong seasonal differences and very low summer ratios were ultimately decisive in controlling summer cyanobacteria. Paerl et al. (2016) postulated that lakes like Müggelsee with annual external input N:P ratios between 9 and 23 (weight) and greater denitrification rates than fixation rates should be N+P limited. Our results concur, albeit with seasonal separation of apparently strict $\mathrm{N}$ and $\mathrm{P}$ limitation. $\mathrm{N}$ limitation is prevalent primarily in shallow polymictic lakes during summer (Dolman et al. 2016). Combined with naturally high seasonal $P$ release rates, polymictic lakes have potentially high denitrification rates due to a generally good supply of fresh organic material and warmer temperatures above the sediment caused by regular mixing. Therefore reductions in $\mathrm{N}$-inputs, which do not necessarily decrease N:P loading ratios below Redfield, may be effective at controlling summer cyanobacterial blooms in polymictic lakes.

This raises the question of why the $\mathrm{N}$ deficit relative to $\mathrm{P}$ was not compensated by $\mathrm{N}_{2}$ fixation through diazotrophic cyanobacteria. Moss et al. (2013) postulated that N-limitation may persist in lakes simply because $\mathrm{N}_{2}$-fixing species are unable to develop substantial populations or when fixed $\mathrm{N}$ is washed out in winter before it can be incorporated into internal lake cycles. The short 
water residence times in estuaries affect their sensitivity to $\mathrm{N}$ loading (Howarth and Marino 2006) and can prevent $\mathrm{N}$ fixed from the atmosphere or released from the sediment from accumulating enough to reach optimal N:P ratios (Schindler 1981). The same should apply to lakes with short residence times like Müggelsee, particularly given that downstream flushing of $\mathrm{N}$ may be more important than $\mathrm{P}$ or $\mathrm{C}$ on global scales (Maranger et al. 2018). However, flushing was unlikely to have prevented an accumulation of fixed nitrogen in the case of Müggelsee. Dilution by flushing is only possible if inflow concentrations are lower than lake concentrations but this was never the case. The fact that TN concentrations in the lake were always lower than in the inflow indicates that denitrification plus sedimentation rates permanently exceeded $\mathrm{N}_{2}$ fixation rates, leading to a net loss of $\mathrm{N}$, even when external $\mathrm{N}$-loading and TN:TP ratios decreased. In fact, our somewhat crude estimates suggest that denitrification plus N-burial rates were many times higher than $\mathrm{N}_{2}$ fixation rates throughout the case history. It has been argued that $\mathrm{N}_{2}$ fixation only balances the reactive $\mathrm{N}$ pool gradually so that $\mathrm{P}$ is the ultimate, long-term limiting nutrient (Schindler 2012; Schindler et al. 2016). Our results do not support this because $\mathrm{N}_{2}$ fixation did not exceed $\mathrm{N}$ losses in the long term (Scott and McCarthy 2010; Paerl et al. 2016). The theoretical residence times were much longer during summer than on annual mean, and they increased during the study period (from $60 \pm 17$ days in summers of the 1980 s to $109 \pm$ 38 days in 2007-16). These residence times were long enough to facilitate cyanobacteria growth, and their extension should increase the importance not only of $\mathrm{N}_{2}$ fixation but also of $\mathrm{N}$ losses like denitrification and sedimentation.

Nitrogen losses were not the only reason why decreases in $\mathrm{N}$ were not compensated in the long term by $\mathrm{N}_{2}$ fixation. Increased $\mathrm{N}$-limitation clearly did not favor $\mathrm{N}_{2}$-fixing species. In fact, all evidence in our results points to the opposite: lower DIN concentrations, lower DIN:SRP, lower $\mathrm{PN}: \mathrm{PP}$ and higher $\mathrm{C}: \mathrm{N}$ all correlated with a lower biovolume and lower proportion of $\mathrm{N}_{2}$-fixing species, showing that increased $\mathrm{N}$-limitation decreased the relative abundance of $\mathrm{N}_{2}$-fixing cyanobacteria. This concurs with the results of Dolman et al. (2012), who found that $\mathrm{N}_{2}$-fixing taxa reached the highest biovolumes in lakes with high N:P ratios. Paerl and Otten (2016) attributed this phenomenon in many cases to physical control by temperature, irradiance and hydrology. This may have been the case in our study because the pre-bloom net specific growth rates of $\mathrm{N}_{2}$-fixing taxa were correlated with light, suggesting light limitation may have played a role. However, light availability did not play the decisive role because, as the biovolume of $\mathrm{N}_{2}$ fixing taxa decreased over time, mean underwater light increased due to higher water transparency coinciding with the lake's recovery. Whereas the per-heterocyst $\mathrm{N}_{2}$ fixation estimated according to Ferber et al. (2004) increased over time due to the increase in light availability, total $\mathrm{N}_{2}$ fixation did not. Moreover there was no correlation between mean underwater light in the summer mixed layer and the proportion of $\mathrm{N}_{2}$-fixing taxa. It is therefore unlikely that light supply constraints prevented $\mathrm{N}_{2}$ fixation from increasing in response to stronger $\mathrm{N}$ limitation. Wagner and Adrian (2009) found that increased stratification duration in 
Müggelsee promoted $\mathrm{N}_{2}$-fixing taxa more than non- $\mathrm{N}_{2}$-fixing cyanobacteria, but only above certain TN and TP thresholds. On the other hand, higher temperatures may favor Microcystis sp. over $\mathrm{N}_{2}$ fixing taxa like Aphanizomenon sp. (Paerl and Otten 2016). Thus the increasing temperature trend we observed without a concurrent change in stratification may in part explain the decrease in proportion of $\mathrm{N}_{2}$ fixing taxa. Higher water transparency decreases summer stratification in Müggelsee (Shatwell et al. 2016), which can explain the absence of trends in stratification despite an increase in water temperature. In general however, we found little evidence that changes in the physical regime constrained $\mathrm{N}_{2}$ fixation or the abundance of $\mathrm{N}_{2}-$ fixing taxa. Alternative explanations may be limitation by micronutrients (Wurtsbaugh 1988) or the fact that $\mathrm{N}$ limitation may not have been strong enough for $\mathrm{N}_{2}$ fixation to yield a competitive advantage (Tyrrell 1999).

The sharp increase in the biovolume-specific number of heterocysts we observed at low DIN concentrations is a typical response of $\mathrm{N}_{2}$-fixing species (Howarth et al. 1988). However, the decrease in biovolume of $\mathrm{N}_{2}$-fixing species cancelled the increase in biovolume-specific heterocyst concentration, so that the total amount of heterocysts did not change over time. Per heterocyst fixation rates tend to be very variable (Hadas et al. 2012) but this finding does not indicate any net increase in $\mathrm{N}_{2}$-fixation over time in response to decreased DIN concentrations or increased mean light intensity in summer.

Altogether our results demonstrate that dual $\mathrm{N}$ and $\mathrm{P}$ control can be an effective strategy to mitigate eutrophication. Particularly in polymictic lakes where summer internal P loading and denitrification rates are potentially high, the lower N-loading can induce stronger summer $\mathrm{N}$ limitation and in turn effectively control cyanobacterial blooms in the long term. Moreover, increased $\mathrm{N}$-limitation does not necessarily promote $\mathrm{N}_{2}$-fixing taxa, and in our study, effectively decreased their biomass.

\section{Acknowledgements}

We thank Thomas Hintze, Bernd Schütze, Reinhard Hölzel, Jürgen Schreiber, Ursula Newen, Sigrid Hoeg, Helgard Täuscher, and Katrin Preuß for sampling and sample processing, and the Leibniz-Institute of Freshwater Ecology and Inland Fisheries (IGB) for the long-term ecological program. We also thank Michael Hupfer, Andrew Dolman and two anonymous reviewers for helpful comments. This work was funded by the German Federal Ministry of Education and Research, grant number 033L041B.

\section{References}

Bracken, M. E. S., H. Hillebrand, E. T. Borer and others 2015. Signatures of nutrient limitation and co-limitation: responses of autotroph internal nutrient concentrations to nitrogen and phosphorus additions. Oikos 124: 113-121. doi:10.1111/oik.01215 
Conley, D. J., H. W. Paerl, R. W. Howarth, D. F. Boesch, S. P. Seitzinger, K. E. Havens, C. Lancelot, and G. E. Likens. 2009. Controlling eutrophication: nitrogen and phosphorus. Science 323: 1014-1015. doi:10.1126/science. 1167755

Cotner, J. B. 2017. Nitrogen is not a 'House of Cards'. Environ. Sci. Technol. 51: 3-3. doi:10.1021/acs.est.6b04890

Cribari-Neto, F., and A. Zeileis. 2010. Beta Regression in R. J Stat Softw 34: 1-24. doi:10.18637/jss.v034.i02

Dee, D. P., S. M. Uppala, A. J. Simmons and others 2011. The ERA-Interim reanalysis: configuration and performance of the data assimilation system. Quarterly Journal of the Royal Meteorological Society 137: 553-597. doi:10.1002/qj.828

DEV. 1983-2012. German standard methods for the examination of water, waste water and sludge. VCH Verlagsges. mbH, Beuth Verlag GmbH.

Dolman, A. M., U. Mischke, and C. Wiedner. 2016. Lake-type-specific seasonal patterns of nutrient limitation in German lakes, with target nitrogen and phosphorus concentrations for good ecological status. Freshwater Biol. 61: 444-456. doi:10.1111/fwb.12718

Dolman, A. M., J. Rücker, F. R. Pick, J. Fastner, T. Rohrlack, U. Mischke, and C. Wiedner. 2012. Cyanobacteria and cyanotoxins: The influence of nitrogen versus phosphorus. PLoS ONE 7: e38757. doi:10.1371/journal.pone.0038757

Driescher, E., H. Behrendt, G. Schellenberger, and R. Stellmacher. 1993. Lake Müggelsee and its environment - natural conditions and anthropogenic impacts. Int. Rev. Gesamten Hydrobiol. 78: 327-343.

Elser, J. J., M. E. S. Bracken, E. E. Cleland and others 2007. Global analysis of nitrogen and phosphorus limitation of primary producers in freshwater, marine and terrestrial ecosystems. Ecol. Lett. 10: 1135-1142. doi:10.1111/j.1461-0248.2007.01113.x

Ferber, L. R., S. N. Levine, A. Lini, and G. P. Livingston. 2004. Do cyanobacteria dominate in eutrophic lakes because they fix atmospheric nitrogen? Freshwater Biol. 49: 690-708. doi:10.1111/j.1365-2427.2004.01218.x

Glibert, P. M., R. Maranger, D. J. Sobota, and L. Bouwman. 2014. The Haber Bosch-harmful algal bloom (HB-HAB) link. Environmental Research Letters 9. doi:10.1088/17489326/9/10/105001

Gobler, C. J., J. M. Burkholder, T. W. Davis, M. J. Harke, T. Johengen, C. A. Stow, and D. B. Van de Waal. 2016. The dual role of nitrogen supply in controlling the growth and toxicity of cyanobacterial blooms. Harmful Algae 54: 87-97. doi:10.1016/j.hal.2016.01.010

Grantz, E. M., B. E. Haggard, and J. T. Scott. 2014. Stoichiometric imbalance in rates of nitrogen and phosphorus retention, storage, and recycling can perpetuate nitrogen deficiency in highly-productive reservoirs. Limnol. Oceanogr. 59: 2203-2216. doi:10.4319/lo.2014.59.6.2203 
Guildford, S. J., and R. E. Hecky. 2000. Total nitrogen, total phosphorus, and nutrient limitation in lakes and oceans: Is there a common relationship? Limnol. Oceanogr. 45: 1213-1223. doi:10.4319/lo.2000.45.6.1213

Hadas, O., R. Pinkas, N. Malinsky-Rushansky, A. Nishri, A. Kaplan, A. Rimmer, and A. Sukenik. 2012. Appearance and establishment of diazotrophic cyanobacteria in Lake Kinneret, Israel. Freshwater Biol. 57: 1214-1227. doi:10.1111/j.1365-2427.2012.02792.x

Harpole, W. S., J. T. Ngai, E. E. Cleland and others 2011. Nutrient co-limitation of primary producer communities. Ecol. Lett. 14: 852-862. doi:10.1111/j.1461-0248.2011.01651.x

Howarth, R. W., and R. Marino. 2006. Nitrogen as the limiting nutrient for eutrophication in coastal marine ecosystems: Evolving views over three decades. Limnol. Oceanogr. 51: 364-376. doi:10.4319/lo.2006.51.1_part_2.0364

Howarth, R. W., R. Marino, and J. J. Cole. 1988. Nitrogen fixation in freshwater, estuarine, and marine ecosystems. 2. Biogeochemical controls1. Limnol. Oceanogr. 33: 688-701. doi:10.4319/lo.1988.33.4part2.0688

Hupfer, M., and J. Lewandowski. 2005. Retention and early diagenetic transformation of phosphorus in Lake Arendsee (Germany) - consequences for management strategies. Arch. Hydrobiol. 164: 143-167. doi:10.1127/0003-9136/2005/0164-0143

---. 2008. Oxygen controls the phosphorus release from lake sediments - a long-lasting paradigm in limnology. International Review of Hydrobiology 93: 415-432. doi:10.1002/iroh.200711054

Jeppesen, E., M. Sondergaard, J. P. Jensen and others 2005. Lake responses to reduced nutrient loading - an analysis of contemporary long-term data from 35 case studies. Freshwater Biol. 50: 1747-1771. doi:10.1111/j.1365-2427.2005.01415.x

Köhler, J., S. Hilt, R. Adrian, A. Nicklisch, H. P. Kozerski, and N. Walz. 2005. Long-term response of a shallow, moderately flushed lake to reduced external phosphorus and nitrogen loading. Freshwater Biol. 50: 1639-1650. doi:10.1111/j.13652427.2005.01430.x

Kolzau, S., A. M. Dolman, M. Voss, and C. Wiedner. 2018. The response of nitrogen fixing cyanobacteria to a reduction in nitrogen loading. International Review of Hydrobiology 103: 5-14. doi:10.1002/iroh.201601882

Lewis, W. M., and W. A. Wurtsbaugh. 2008. Control of lacustrine phytoplankton by nutrients: Erosion of the phosphorus paradigm. International Review of Hydrobiology 93: 446-465. doi:10.1002/iroh.200811065

Maranger, R., S. E. Jones, and J. B. Cotner. 2018. Stoichiometry of carbon, nitrogen, and phosphorus through the freshwater pipe. Limnology and Oceanography Letters 3: 89101. doi:doi:10.1002/lol2.10080

McCrackin, M. L., H. P. Jones, P. C. Jones, and D. Moreno-Mateos. 2017. Recovery of lakes and coastal marine ecosystems from eutrophication: A global meta-analysis. Limnol. Oceanogr. 62: 507-518. doi:10.1002/lno.10441 
Moss, B., T. O. M. Barker, D. Stephen, A. E. Williams, D. J. Balayla, M. Beklioglu, and L. Carvalho. 2005. Consequences of reduced nutrient loading on a lake system in a lowland catchment: deviations from the norm? Freshwater Biol. 50: 1687-1705. doi:10.1111/j.1365-2427.2005.01416.x

Moss, B., E. Jeppesen, M. Sondergaard, T. L. Lauridsen, and Z. Liu. 2013. Nitrogen, macrophytes, shallow lakes and nutrient limitation: resolution of a current controversy? Hydrobiologia 710: 3-21. doi:10.1007/s10750-012-1033-0

Murphy, J., and J. P. Riley. 1962. A modified single solution method for the determination of phosphate in natural waters. Anal. Chim. Acta 27: 31-36. doi:10.1016/S00032670(00)88444-5

Nicklisch, A., T. Shatwell, and J. Köhler. 2008. Analysis and modelling of the interactive effects of temperature and light on phytoplankton growth and relevance for the spring bloom. J. Plankton Res. 30: 75-91. doi:10.1093/plankt/fbm099

Paerl, H. W. 2009. Controlling eutrophication along the freshwater-marine continuum: Dual nutrient $(\mathrm{N}$ and $\mathrm{P}$ ) reductions are essential. Estuaries and Coasts 32: 593-601. doi:10.1007/s12237-009-9158-8

Paerl, H. W., and T. G. Otten. 2016. Duelling 'CyanoHABs': unravelling the environmental drivers controlling dominance and succession among diazotrophic and non- $\mathrm{N}_{2}$-fixing harmful cyanobacteria. Environ. Microbiol. 18: 316-324. doi:10.1111/1462-2920.13035

Paerl, H. W., J. T. Scott, M. J. McCarthy and others 2016. It takes two to tango: When and where dual nutrient $(\mathrm{N} \& \mathrm{P})$ reductions are needed to protect lakes and downstream ecosystems. Environ. Sci. Technol. 50: 10805-10813. doi:10.1021/acs.est.6b02575

Peñuelas, J., B. Poulter, J. Sardans and others 2013. Human-induced nitrogen-phosphorus imbalances alter natural and managed ecosystems across the globe. Nature Communications 4: 2934. doi:10.1038/ncomms3934

R Core Team. 2017. R: A language and environment for statistical computing. R Foundation for Statistical Computing.

Schindler, D. W. 1977. Evolution of phosphorus limitation in lakes. Science 195: 260-262. doi:10.1126/science.195.4275.260

---. 1981. Studies of eutrophication in lakes and their relevance to the estuarine environment, $p$. 71-82. In B. J. Neilson and L. E. Cronin [eds.], Estuaries and Nutrients. Contemporary Issues in Science and Society. Humana Press.

---. 2012. The dilemma of controlling cultural eutrophication of lakes. Proceedings of the Royal Society of London B: Biological Sciences. doi:10.1098/rspb.2012.1032

Schindler, D. W., S. R. Carpenter, S. C. Chapra, R. E. Hecky, and D. M. Orihel. 2016. Reducing phosphorus to curb lake eutrophication is a success. Environ. Sci. Technol. 50: 89238929. doi:10.1021/acs.est.6b02204 
Schindler, D. W., S. R. Carpenter, S. C. Chapra, R. E. Hecky, and D. M. Orihel. 2017. Response to the letter, Nitrogen is Not a "House of Cards". Environ. Sci. Technol. 51: 1943-1943. doi:10.1021/acs.est.6b06106

Schindler, D. W., R. E. Hecky, D. L. Findlay and others 2008. Eutrophication of lakes cannot be controlled by reducing nitrogen input: Results of a 37-year whole-ecosystem experiment. Proceedings of the National Academy of Sciences 105: 11254-11258. doi:10.1073/pnas.0805108105

Scott, J. T., and E. M. Grantz. 2013. $\mathrm{N}_{2}$ fixation exceeds internal nitrogen loading as a phytoplankton nutrient source in perpetually nitrogen-limited reservoirs. Freshw Sci 32: 849-861. doi:10.1899/12-190.1

Scott, J. T., and M. J. McCarthy. 2010. Nitrogen fixation may not balance the nitrogen pool in lakes over timescales relevant to eutrophication management. Limnol. Oceanogr. 55: 1265-1270. doi:10.4319/lo.2010.55.3.1265

Shatwell, T., R. Adrian, and G. Kirillin. 2016. Planktonic events may cause polymictic-dimictic regime shifts in temperate lakes. Scientific Reports 6: 24361. doi:10.1038/srep24361

Sinke, A. J. C., A. A. Cornelese, P. Keizer, O. F. R. Tongeren, and T. E. Cappenberg. 1990. Mineralization, pore water chemistry and phosphorus release from peaty sediments in the eutrophic Loosdrecht lakes, The Netherlands. Freshwater Biol. 23: 587-599. doi:10.1111/j.1365-2427.1990.tb00297.x

Song, K., and A. J. Burgin. 2017. Perpetual phosphorus cycling: Eutrophication amplifies biological control on internal phosphorus loading in agricultural reservoirs. Ecosystems 20: 1483-1493. doi:10.1007/s10021-017-0126-z

Tyrrell, T. 1999. The relative influences of nitrogen and phosphorus on oceanic primary production. Nature 400: 525. doi:10.1038/22941

Wagner, C., and R. Adrian. 2009. Cyanobacteria dominance: Quantifying the effects of climate change. Limnol. Oceanogr. 54: 2460-2468. doi:10.4319/lo.2009.54.6_part_2.2460

Wang, H., and H. Wang. 2009. Mitigation of lake eutrophication: Loosen nitrogen control and focus on phosphorus abatement. Progress in Natural Science 19: 1445-1451. doi:http://dx.doi.org/10.1016/j.pnsc.2009.03.009

Welch, E. B. 2009. Should nitrogen be reduced to manage eutrophication if it is growth limiting? Evidence from Moses Lake. Lake Reserv. Manage. 25: 401-409. doi:10.1080/07438140903323757

Wurtsbaugh, W. A. 1988. Iron, molybdenum and phosphorus limitation of N2 fixation maintains nitrogen deficiency of plankton in the Great Salt Lake drainage (Utah, USA). SIL Proceedings, 1922-2010 23: 121-130. doi:10.1080/03680770.1987.11897913 


\section{Tables}

Table 1: Mean ( \pm s.e.) nitrogen and phosphorus concentrations and ratios (by weight) in Müggelsee by season for the period 1979 - 2014 (C:N ratios only since 1999). Trends over time are given in parentheses with the following significance codes: ns: not significant, $*: p<0.05$, $* *: \mathrm{p}<0.01, * * *: \mathrm{p}<0.001$. For nutrient concentrations, the table shows arithmetic means and trends in concentration units per year. For nutrient ratios, the table shows geometric means with trends in percent per year.

\begin{tabular}{|c|c|c|c|c|c|}
\hline & Winter & Spring & Summer & Autumn & Annual \\
\hline $\mathrm{TP}\left(\mu \mathrm{g} \mathrm{L}^{-1}\right)$ & $\begin{array}{c}78 \pm 3.5 \\
\left(-1.3 \mu g \mathrm{~L}^{-1} \mathrm{a}^{-}\right. \\
1)^{* * *}\end{array}$ & $\begin{array}{c}89 \pm 4.9 \\
\left(-2.0 \mu \mathrm{g} \mathrm{L}^{-1} \mathrm{a}^{-}\right. \\
1) * * *\end{array}$ & $\begin{array}{c}226 \pm 17 \\
\left(-3.4 \mu \mathrm{g} \mathrm{L}^{-1} \mathrm{a}^{-1}\right)^{*}\end{array}$ & $\begin{array}{c}144 \pm 8.9 \\
\text { (ns) }\end{array}$ & $\begin{array}{c}134 \pm 6.9 \\
\left(-1.8 \mu \mathrm{g} \mathrm{L}^{-1} \mathrm{a}^{-}\right. \\
1)^{* *}\end{array}$ \\
\hline $\operatorname{SRP}\left(\mu \mathrm{g} \mathrm{L}^{-1}\right)$ & $\begin{array}{c}29 \pm 1.3 \\
\left(-0.33 \mu \mathrm{g} \mathrm{L}^{-1} \mathrm{a}^{-}\right. \\
1)^{* *}\end{array}$ & $\begin{array}{c}17 \pm 1.2 \\
(\mathrm{~ns})\end{array}$ & $\begin{array}{c}122 \pm 12.5 \\
(\mathrm{~ns})\end{array}$ & $\begin{array}{c}89 \pm 7.9 \\
(\mathrm{~ns})\end{array}$ & $\begin{array}{c}64.1 \pm 5.1 \\
(\mathrm{~ns})\end{array}$ \\
\hline $\mathrm{TN}\left(\mathrm{mg} \mathrm{L}^{-1}\right)$ & $\begin{array}{c}2.22 \pm 0.17 \\
\left(-0.075 \mathrm{mg} \mathrm{L}^{-1} \mathrm{a}^{-}\right. \\
1)^{* * *}\end{array}$ & $\begin{array}{c}1.61 \pm 0.13 \\
\left(-0.061 \mathrm{mg} \mathrm{L}^{-1} \mathrm{a}^{-}\right. \\
1)^{* * *}\end{array}$ & $\begin{array}{c}1.30 \pm 0.07 \\
\left(-0.033 \mathrm{mg} \mathrm{L}^{-1} \mathrm{a}^{-}\right. \\
1) * * *\end{array}$ & $\begin{array}{c}1.41 \pm 0.08 \\
\left(-0.036 \mathrm{mg} \mathrm{L}^{-1}\right. \\
\left.\mathrm{a}^{-1}\right)^{* * *}\end{array}$ & $\begin{array}{c}1.64 \pm 0.07 \\
\left(-0.050 \mathrm{mg} \mathrm{L}^{-1}\right. \\
\left.\mathrm{a}^{-1}\right)^{* * *}\end{array}$ \\
\hline $\mathrm{DIN}\left(\mathrm{mg} \mathrm{L}^{-1}\right)$ & $\begin{array}{c}1.68 \pm 0.22 \\
\left(-0.074 \mathrm{mg} \mathrm{L}^{-1} \mathrm{a}^{-}\right. \\
1)^{* * *}\end{array}$ & $\begin{array}{c}0.57 \pm 0.06 \\
\left(-0.025 \mathrm{mg} \mathrm{L}^{-1} \mathrm{a}^{-}\right. \\
1)^{* * *}\end{array}$ & $\begin{array}{c}0.22 \pm 0.03 \\
\left(-0.010 \mathrm{mg} \mathrm{L}^{-1} \mathrm{a}^{-}\right. \\
1) * * *\end{array}$ & $\begin{array}{c}0.77 \pm 0.09 \\
\left(-0.031 \mathrm{mg} \mathrm{L}^{-1}\right. \\
\left.\mathrm{a}^{-1}\right)^{* * *}\end{array}$ & $\begin{array}{c}0.85 \pm 0.08 \\
\left(-0.039 \mathrm{mg} \mathrm{L}^{-1}\right. \\
\left.\mathrm{a}^{-1}\right)^{* * *}\end{array}$ \\
\hline TN:TP & $\begin{array}{c}27.1 \pm 6.4 \% \\
\left(-1.6 \% \mathrm{a}^{-1}\right)^{* *}\end{array}$ & $\begin{array}{l}18.4 \pm 5.2 \% \\
\left(-1.1 \% \mathrm{a}^{-1}\right)^{*}\end{array}$ & $\begin{array}{c}6.7 \pm 5.5 \% \\
(\mathrm{~ns})\end{array}$ & $\begin{array}{c}11.3 \pm 7.5 \% \\
\left(-1.9 \% \mathrm{a}^{-1}\right)^{* *}\end{array}$ & $\begin{array}{c}16.1 \pm 5.1 \% \\
\left(-1.4 \% \mathrm{a}^{-1}\right)^{* *}\end{array}$ \\
\hline DIN:SRP & $\begin{array}{l}75.0 \pm 10.5 \% \\
\left(-2.5 \% \mathrm{a}^{-1}\right)^{* *}\end{array}$ & $\begin{array}{c}67.7 \pm 18.0 \% \\
\left(-5.2 \% \mathrm{a}^{-1}\right)^{* * *}\end{array}$ & $\begin{array}{l}2.41 \pm 19.5 \% \\
\left(-5.3 \% \mathrm{a}^{-1}\right) * * *\end{array}$ & $\begin{array}{c}10.1 \pm 15.9 \% \\
\left(-5.4 \% \mathrm{a}^{-1}\right)^{* * *}\end{array}$ & $\begin{array}{l}41.4 \pm 12.9 \% \\
\left(-4.0 \% \mathrm{a}^{-1}\right) * * *\end{array}$ \\
\hline $\mathrm{PN}: \mathrm{PP}$ & $\begin{array}{c}5.4 \pm 5.5 \% \\
(\mathrm{~ns})\end{array}$ & $\begin{array}{c}7.1 \pm 7.3 \% \\
\left(-2.0 \% \mathrm{a}^{-1}\right)^{* * *}\end{array}$ & $\begin{array}{c}5.6 \pm 6.5 \% \\
\left(-2.8 \% \mathrm{a}^{-1}\right)^{* * *}\end{array}$ & $\begin{array}{c}4.9 \pm 6.1 \% \\
\text { (ns) }\end{array}$ & $\begin{array}{c}5.9 \pm 4.7 \% \\
\left(-1.3 \% \mathrm{a}^{-1}\right)^{* * *}\end{array}$ \\
\hline DIN:TP & $\begin{array}{c}18.2 \pm 9.6 \% \\
\left(-2.6 \% \mathrm{a}^{-1}\right)^{* * *}\end{array}$ & $\begin{array}{l}6.6 \pm 12.6 \% \\
\left(-3.0 \% \mathrm{a}^{-1}\right)^{* *}\end{array}$ & $\begin{array}{l}0.9 \pm 13.4 \% \\
\left(-3.4 \% \mathrm{a}^{-1}\right)^{* *}\end{array}$ & $\begin{array}{c}5.7 \pm 11.8 \% \\
\left(-3.5 \% \mathrm{a}^{-1}\right)^{* * *}\end{array}$ & $\begin{array}{c}8.2 \pm 9.4 \% \\
\left(-2.8 \% \mathrm{a}^{-1}\right) * * *\end{array}$ \\
\hline $\mathrm{C}: \mathrm{N}$ & $\begin{array}{c}6.2 \pm 5.4 \% \\
\left(3.3 \% \mathrm{a}^{-1}\right)^{* * *}\end{array}$ & $\begin{array}{c}5.8 \pm 4.2 \% \\
\left(2.3 \% \mathrm{a}^{-1}\right)^{* * *}\end{array}$ & $\begin{array}{c}5.6 \pm 4.3 \% \\
\left(2.5 \% \mathrm{a}^{-1}\right)^{* * *}\end{array}$ & $\begin{array}{c}6.2 \pm 6.6 \% \\
\left(3.9 \% \mathrm{a}^{-1}\right)^{* * *}\end{array}$ & $\begin{array}{c}5.9 \pm 4.6 \% \\
\left(3.0 \% \mathrm{a}^{-1}\right)^{* * *}\end{array}$ \\
\hline
\end{tabular}


Table 2: Results of regressions of total phytoplankton biovolume $\left(\mathrm{mm}^{3} \mathrm{~L}^{-1}\right)$ on total phosphorus (TP, $\mu \mathrm{g} \mathrm{L}^{-1}$ ) or total nitrogen $\left(\mathrm{TN}, \mathrm{mg} \mathrm{L}^{-1}\right)$. Values in parentheses are $95 \%$ confidence intervals of the coefficients. The pseudo $\mathrm{R}^{2}$ was calculated as 1 - model deviance / null deviance.

\begin{tabular}{|l|l|l|l|l|}
\hline Regression equation & $\begin{array}{l}\text { pseudo } \\
\mathbf{R}^{2}\end{array}$ & $\mathbf{d f}$ & $\mathbf{t}$ & $\mathbf{p}$ \\
\hline Spring biovolume $=0.150(0.12-0.18) \times \mathrm{TP}-4.74(-6.1--3.1)$ & 0.74 & 35 & 11.4 & $<<0.0001$ \\
\hline Spring biovolume $=5.89(4.3-7.7) \times \mathrm{TN}-0.79(-2.7-1.3)$ & 0.62 & 36 & 6.7 & $<<0.0001$ \\
\hline Summer biovolume $=0.037(0.011-0.064) \times \mathrm{TP}+1.92(-2.3-7.5)$ & 0.24 & 36 & 3.6 & 0.001 \\
\hline $\begin{array}{l}\text { Summer biovolume }=11.23(8.87-13.71) \times \mathrm{TN}-4.48(-6.84-- \\
1.96)\end{array}$ & 0.71 & 36 & 9.3 & $<<0.0001$ \\
\hline $\begin{array}{l}\text { Annual biovolume }=0.071(0.048-0.091) \times \mathrm{TP}-2.36(-4.21- \\
0.27)\end{array}$ & 0.47 & 36 & 7.2 & $<<0.0001$ \\
\hline Annual biovolume $=4.84(3.52-6.31) \times \mathrm{TN}-1.00(-2.75-0.82)$ & 0.60 & 36 & 6.7 & $<<0.0001$ \\
\hline
\end{tabular}




\section{Figures}

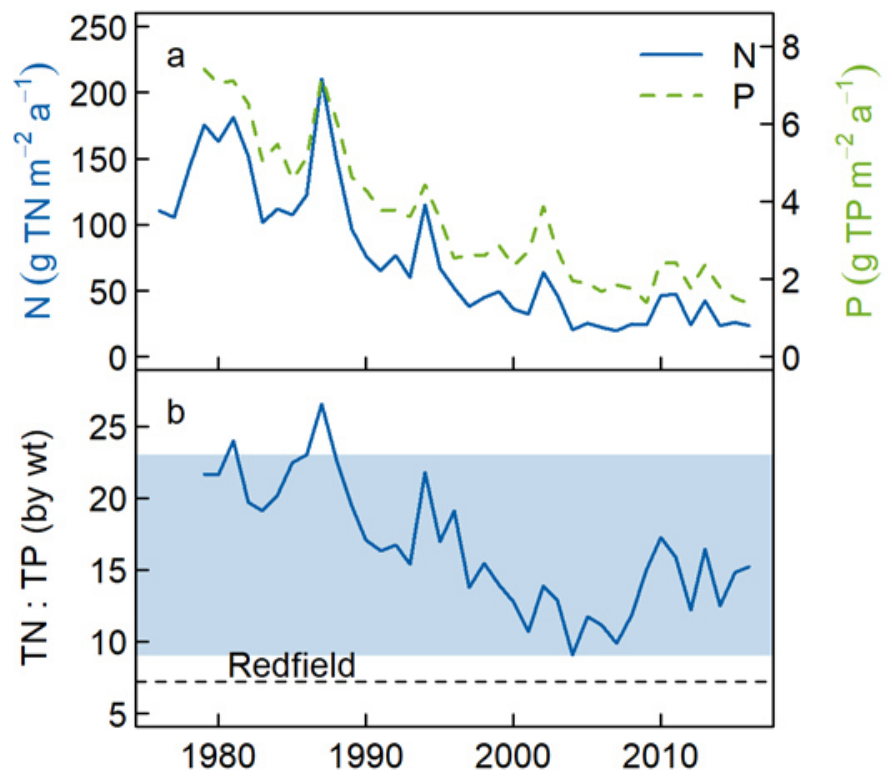

Fig. 1: Annual loads of total nitrogen and total phosphorus (a) and their ratio by weight in inflows (b). The dashed line in (b) indicates the Redfield ratio and the shaded area shows the range of $\mathrm{N}+\mathrm{P}$ co-limitation $(9 \leq \mathrm{TN}$ :TP $\leq 23)$ suggested by Guildford and Hecky (2000). Strict $\mathrm{P}$ or $\mathrm{N}$ limitation occurs outside this region. 


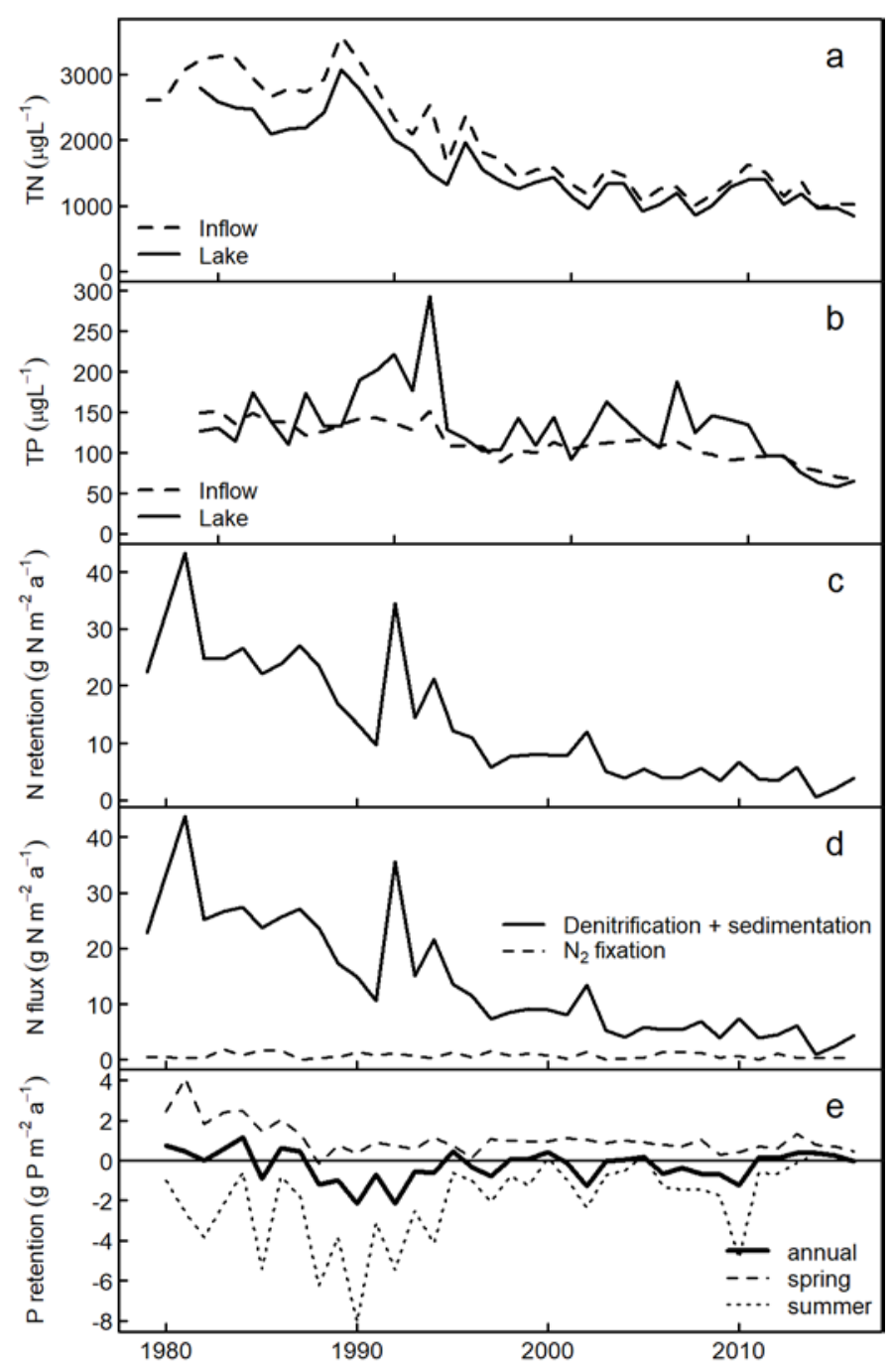

Fig. 2: Annual mean concentrations of total nitrogen (TN; a) and total phosphorus (TP; b) in the inflow (dashed lines) and in the lake (solid lines), as well as retention of nitrogen $(\mathrm{N} ; \mathrm{c})$ and phosphorus $(\mathrm{P} ; \mathrm{e})$ from the nutrient balance, and the estimated contribution of denitrification plus sedimentation and $\mathrm{N}_{2}$ fixation $(\mathrm{d})$. 


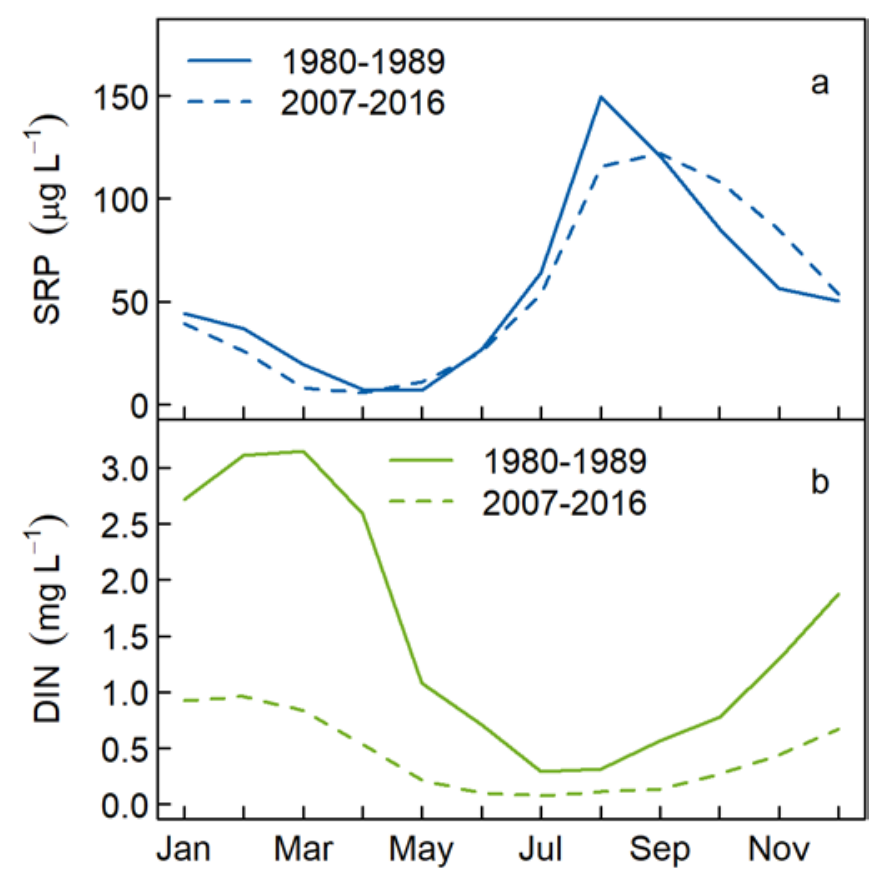

Fig. 3: Monthly means of soluble reactive phosphorus (SRP; a) and dissolved inorganic nitrogen (DIN; b) for the decades 1980-1989 (solid lines) and 2007-2016 (dashed lines). 

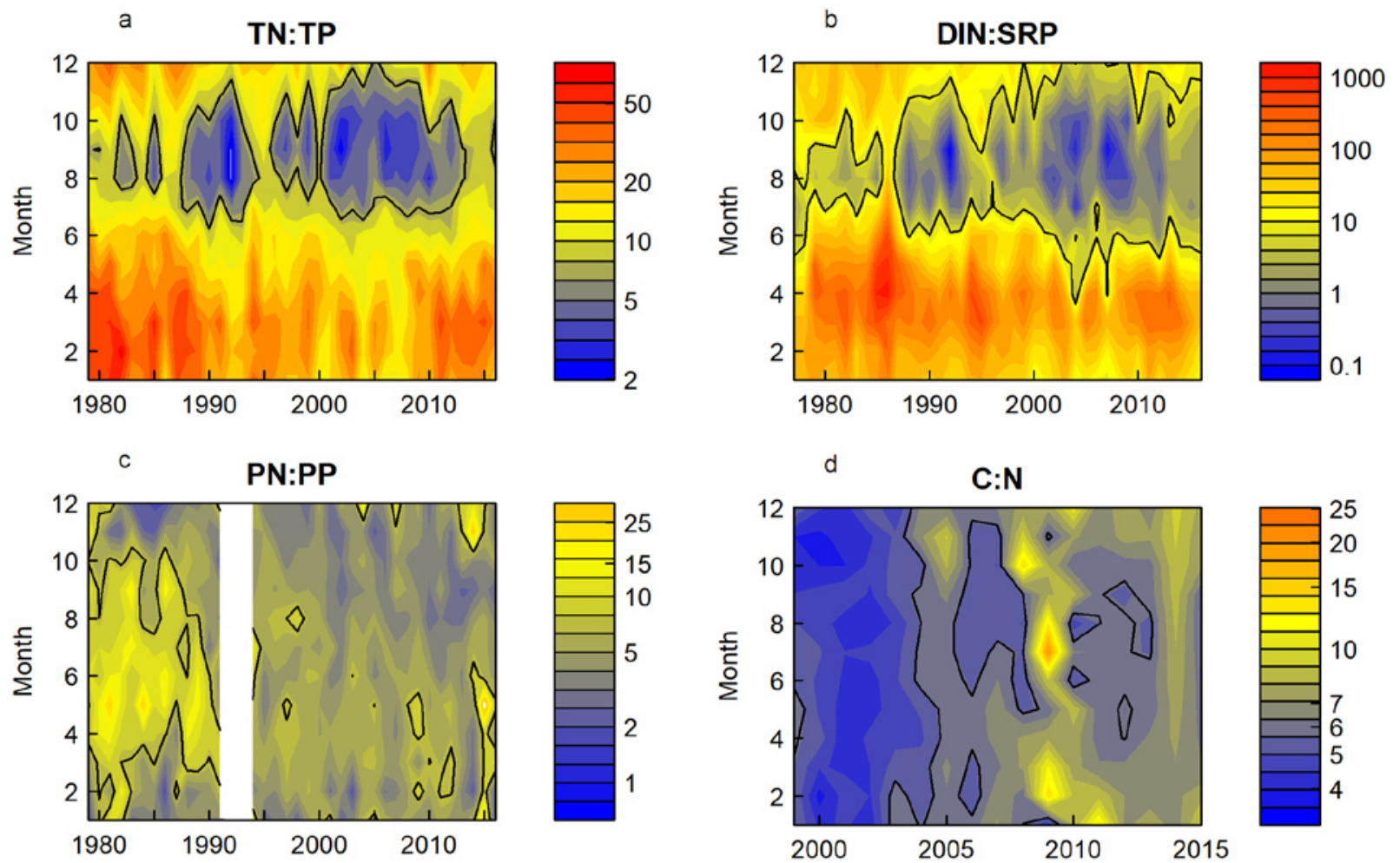

Fig. 4: Seasonal development of nutrient ratios (by weight). Total nitrogen : phosphorus (a), dissolved inorganic nitrogen : soluble reactive phosphorus (b), particulate nitrogen : phosphorus (c) and particulate carbon : nitrogen (d). Black lines delimit areas below the Redfield ratio. 


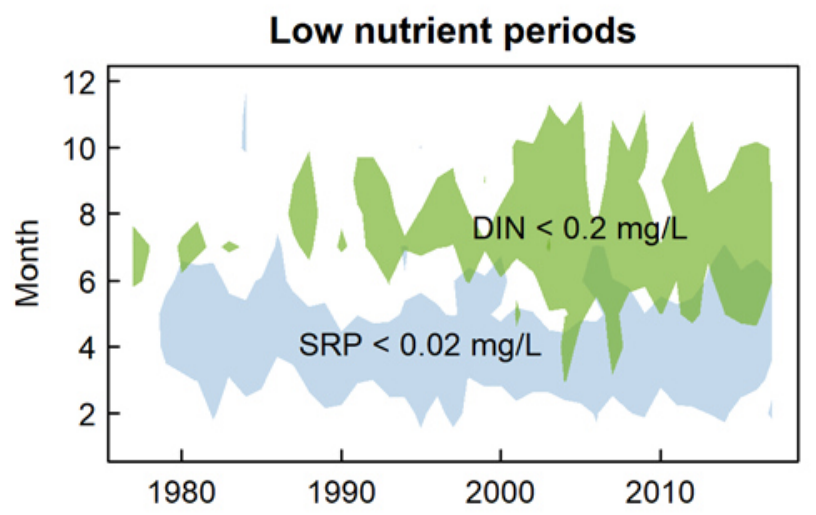

Fig. 5: Occurrence of low dissolved inorganic nutrient concentrations. Blue areas show periods of soluble reactive phosphorus (SRP) below $20 \mu \mathrm{g} \mathrm{L}^{-1}$ and green areas show periods of dissolved inorganic nitrogen (DIN) below $0.2 \mathrm{mg} \mathrm{L}^{-1}$. 


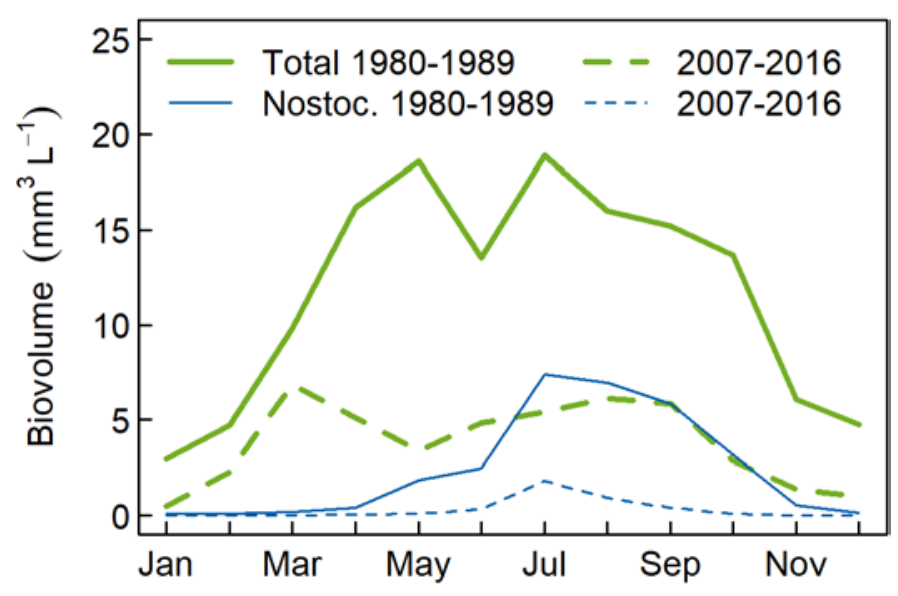

Fig. 6: Seasonal course of the biovolume of total phytoplankton (thick green lines) and $\mathrm{N}_{2}$-fixing cyanobacteria (Nostocales, thin blue lines), averaged over the decade 1980-1989 (solid lines) and 2007-2016 (dashed lines). 


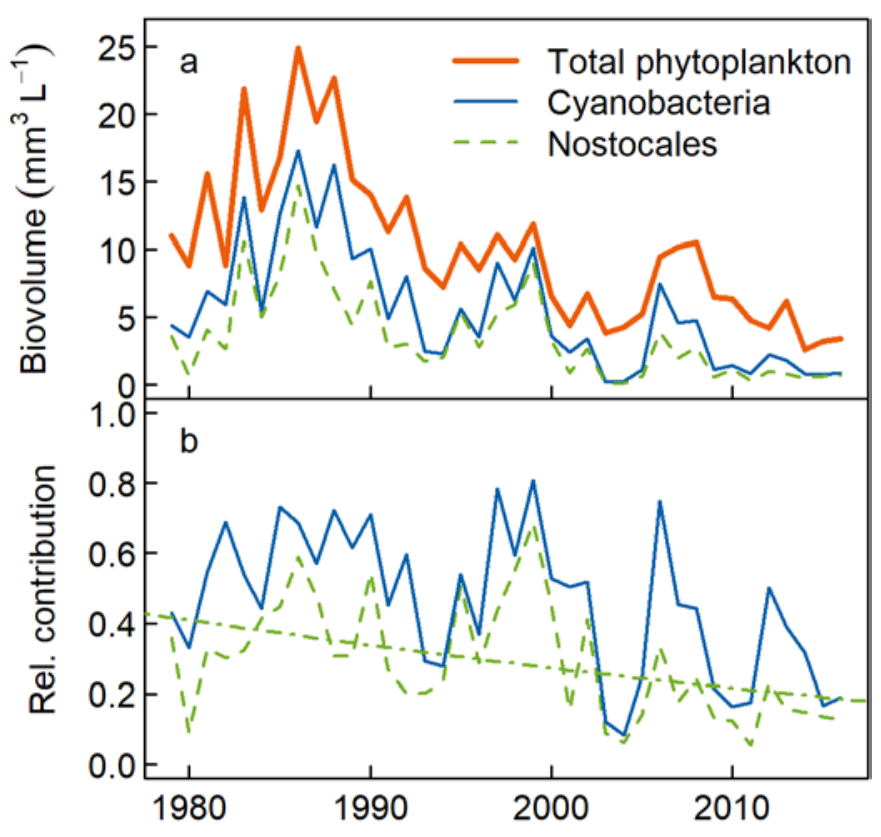

Fig. 7: Annual means of the biovolume of total phytoplankton, cyanobacteria, $\mathrm{N}_{2}$-fixing taxa (Nostocales) (a), and the relative contributions of cyanobacteria and Nostocales within the total phytoplankton (b). The dot-dashed line in (b) is the regression line for Nostocales. 


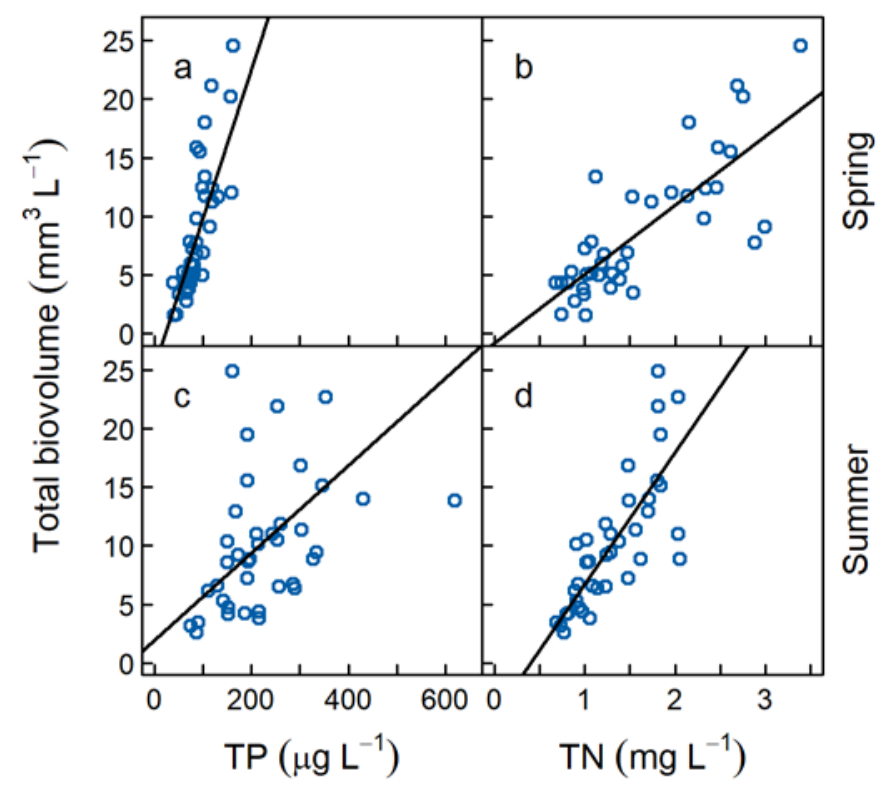

Fig. 8: Relationship between total phytoplankton biovolume and total phosphorus (a, c) and total nitrogen concentration $(b, d)$ in spring $(a, b)$ and summer $(c, d)$. 


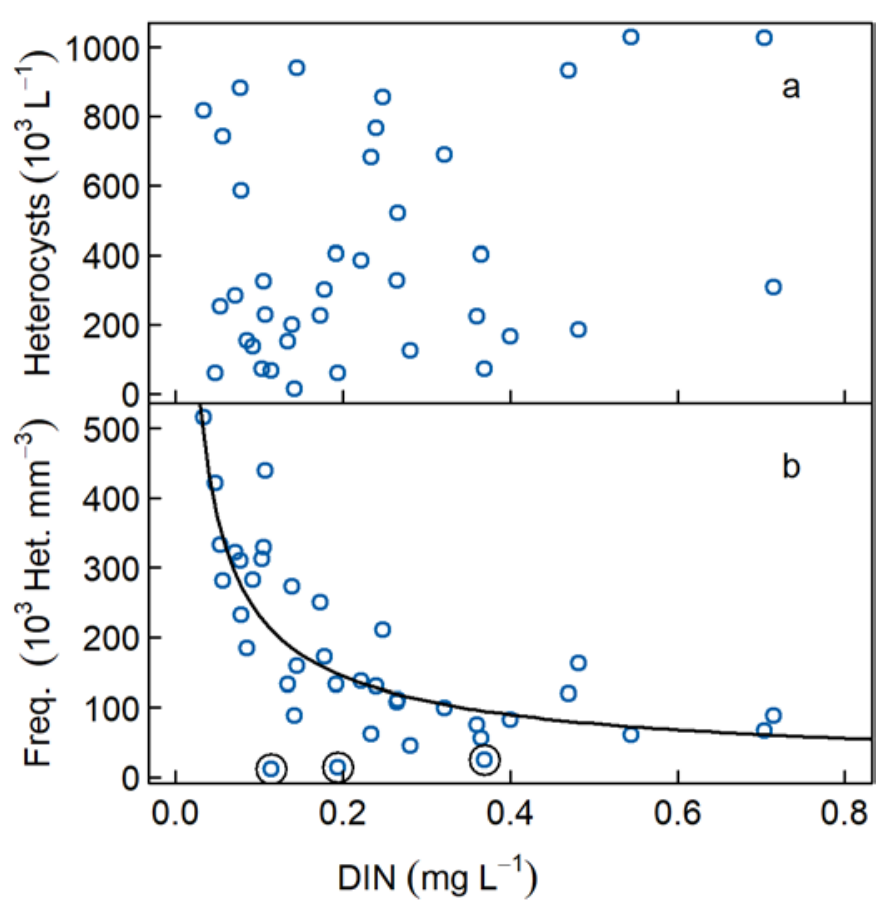

Fig. 9: Mean concentration of heterocysts per liter (a), and per unit biovolume of nitrogen-fixing species (b) as a function of mean dissolved inorganic nitrogen concentration (DIN) during summer (Jul - Sep). Influential years (1987-1989, circled values) were excluded from the regression in (b). 


\section{Supplementary material}

"Decreased nitrogen loading controls summer cyanobacterial blooms without promoting nitrogenfixing taxa: long-term response of a shallow lake", by Tom Shatwell and Jan Köhler.

This supplementary figure gives an example of two years of data (2010-2011) from Müggelsee to illustrate how deep water oxygen and stratification are related to internal nutrient loading. Internal phosphorus loading increases dramatically in summer and contributes to very low TN:TP. Müggelsee periodically forms an oxycline, but this is generally short-lived, interrupted by mixing. The vast majority of stratification events are less than 24 hours in duration (median $6 \mathrm{~h}$ ). The lake can stratify for some weeks during heatwaves, as shown for example in July 2010 in the figure below. Oxygen becomes rapidly depleted followed by a spike in deep water SRP, which translates into a spike in whole water column SRP when the lake mixes again. However, the pattern observed in 2011 is more typical, where stratification events are short and numerous and deep water generally remains oxic.

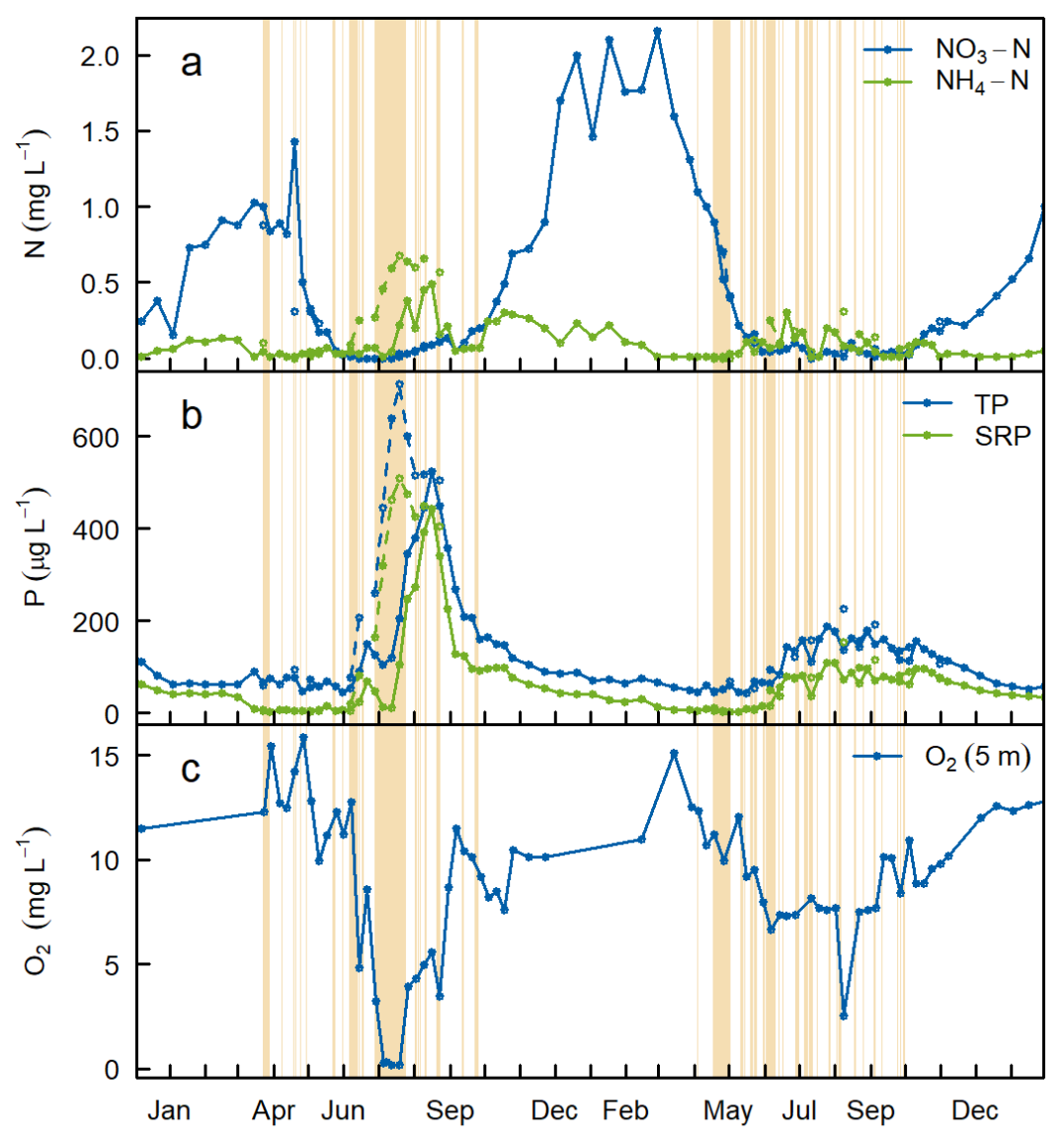

Fig S1: Nitrogen (a, as nitrate and ammonium), phosphorus (b, as total phosphorus and soluble reactive phosphorus) and near-sediment ( $5 \mathrm{~m}$ depth) oxygen concentrations (c) in Müggelsee from the start of 2010 to the end of 2011. Beige background stripes show periods of stratification. Dashed lines in (a) and (b) show mean hypolimnetic nutrient concentrations during stratified periods. The solid lines in (a) and (b) show epilimnion concentrations during stratification or whole water column concentrations otherwise when the lake is mixed. 